\title{
Debate sobre as relações entre educação, formação humana e ontologia a partir do método dialético
}

\author{
Dermeval Saviani*
}

\begin{abstract}
Resumo
O tema "Educação, formação humana e ontologia" é abordado a partir do método dialético e em articulação com o problema das controvérsias no campo marxista motivado pela tese de doutorado $A$ relação entre capital e educaçáo escolar na obra de Dermeval Saviani: apontamentos críticos. Partindo do método de conhecimento desenvolvido por Marx considera-se o significado do tema, referente à relação entre educação, formação humana e ontologia, e responde, na sequência, algumas das objeçôes formuladas no âmbito da controvérsia levantada pela mencionada tese de doutoramento. Na construção do texto procedeu-se a uma argumentação distribuída em quatro momentos. Após uma introduçáo situando a emergência do debate expóese, no segundo momento, o significado do método dialético tomando como referência a formulação teórica de Marx. O terceiro momento é dedicado ao esclarecimento das controvérsias ilustradas por meio de alguns exemplos. Na breve conclusão, destacase o caráter da pedagogia histórico-crítica como teoria da educação formulada em consonância com o materialismo histórico.
\end{abstract}

Palavras-chave: Marxismo. Abordagem histórico-crítica. Debate educacional.

\footnotetext{
*Professor Emérito da Universidade Estadual de Campinas - UNICAMP. Pesquisador Emérito do CNPq e Coordenador Geral do Grupo Nacional de Estudos e Pesquisas "História, Sociedade e Educaçáo no Brasil (HISTEDBR). Atua nas áreas de teorias da educaçáo, história da educaçáo, filosofia da educação, política educacional, formação docente.
} 


\section{Introdução}

O presente artigo reproduz, com pequenos ajustes, a exposição feita na Mesa Redonda "Educação, Formação Humana e Ontologia", realizada no dia 14 de abril de 2011, em Florianópolis, no âmbito do V Encontro Brasileiro de Educação e Marxismo (V EBEM).

A Comissão Organizadora do referido evento, formalizou o convite para minha participação na mencionada Mesa Temática "Educação, Formaçãoo Humana e Ontologia", enviando-me mensagem em 4 de outubro de 2010. Na verdade, eu não poderia participar, pois no dia 14 de abril de 2011 eu deveria estar no Rio Grande do Sul para um compromisso importante. Considerando o caráter do evento, em nome da causa do marxismo consegui ajeitar minha agenda para estar presente e empenhado em colaborar para o objetivo que nos é comum de aclarar melhor, a partir da temática específica da Mesa, nosso entendimento sobre as relações entre o marxismo, a educação e a emancipação humana, tema central do V EBEM. Aceitei, pois, acreditando que as diferenças de enfoque que com certeza emergiriam dos vários participantes do evento enriqueceriam a perspectiva comum que nos une e nos move a atuar em várias frentes de batalha.

Entretanto, o ano de 2010 se encerrou e já estávamos nos aproximando da data do EBEM quando, em fevereiro, me chegaram informaçóes dando conta de que se abria uma cisão no pequeno grupo de educadores marxistas e uma controvérsia se anunciava.

Por um dever de lealdade para com os participantes do evento informei de que controvérsia eu estava falando. $\mathrm{Na}$ verdade seria hipocrisia proceder como se não tivesse conhecimento da tese de doutoramento de Ademir Lazarini (2010), mesmo porque ela já estava circulando. Além disso, também estava circulando amplamente o artigo "A pedagogia histórico-crítica e o marxismo: equívocos de (mais) uma crítica à obra de Dermeval Saviani” (DUARTE, 2011), de Newton Duarte, Benedito Ferreira, Julia Malanchen e Herrmann de Oliveira Muller, que respondeu às críticas da referida tese que foi defendida no Programa de Pós-Graduação em Educação da UFSC em 3 de dezembro de 2010, intitulada "A relação entre capital e educação escolar na obra de Dermeval Saviani: apontamentos críticos”.

De fato, a referida tese não traz novidade, pois retoma as críticas formuladas por Sérgio Lessa, Ivo Tonet e Paulo Sérgio Tumolo, além de recuperar 
outros estudos críticos do final dos anos de 1980 e início dos anos 1990. Aliás, acho de interesse informar que evitei responder diretamente a essas críticas anteriores e fui reunindo os trabalhos que as veiculavam para, caso tornasse necessário, procurar responder a todas conjuntamente. Entretanto, o desenrolar dos acontecimentos se encarregou de relegá-las ao esquecimento, sendo que seus próprios autores, que eu saiba, a elas não voltaram. Então, seguindo o exemplo dos fundadores do marxismo, resolvi abandoná-las à crítica roedora dos ratos. Mas agora boa parte delas retorna na tese do Lazarini. Talvez o que sua tese traga de novo seja justamente o fato de reunir num só trabalho um conjunto de críticas formuladas de forma mais ou menos esparsa, além do caráter bombástico em que as denúncias são apresentadas, como se pode ver pela leitura apenas do sumário da tese.

Como se observou, não foi surpresa o conteúdo da tese. E, como o debate é sempre bem-vindo, o fato de reunir num único trabalho o conjunto das críticas não deixaria de ser positivo porque facilitaria o acesso a elas. A grande surpresa foi o fato de ter sido produzida ao longo de aproximadamente cinco anos, sem que nenhum contato fosse feito comigo. Assim, parece ter havido um problema metodológico da pesquisa, porque seu autor elegeu um objeto, mas não tomou nenhuma iniciativa em conhecê-lo diretamente. Ora, nós sabemos que quando nos dispomos a estudar a obra de um autor vivo, resulta um procedimento necessário: o contato com ele. Isso, inclusive, permitiria ao autor da tese assegurar-se melhor de seus argumentos tornando as críticas mais consistentes, além de possibilitar o acesso a trabalhos que eventualmente seu levantamento poderia náo contemplar. Vejo que Lazarini registra em sua Introdução que realizou "análises de todos os livros e textos de Saviani aos quais tive acesso, referentes ao período delimitado neste estudo, independentemente se os mesmos estavam diretamente relacionados ao tema central da minha pesquisa" (LAZARINI, 2010, p. 34), e constato que ele não teve acesso a muita coisa. Por exemplo, ficaram de fora praticamente todos os meus trabalhos no campo da história e da historiografia, apesar dele ter ousado introduzir em sua tese uma crítica também à minha abordagem historiográfica. Pois bem, se ele tivesse entrado em contato comigo, de bom grado eu lhe passaria todo esse material. Acresce que, ao não ter entrado em contato, de certo modo ele deslocou seu trabalho da intençáo do debate. Pois, sendo essa a intenção, caberia já dar início ao debate no próprio processo de elaboração da tese. Da forma como aconteceu, não fui tratado como um companheiro do mesmo campo 
teórico-político-ideológico a quem se endereçam críticas para fazê-lo avançar ou para corrigir os desvios detectados em sua apropriaçáo da teoria, no caso, o marxismo. De fato, fui tratado como o inimigo a abater.

O que de algum modo me entristece nesse episódio é que fiquei com a impressão de que Ademir tem um grande potencial para o trabalho intelectual revelando grande capacidade de leitura e dissecação de textos. E acabou desperdiçando tanta energia com um objeto não apropriado. E não resisto, aqui, a uma analogia: sua força produtiva intelectual foi travada pelas relaçôes de produçáo intelectual em que se envolveu.

Tornado transparente o quadro em que se deu minha participação no V EBEM, fiz um esforço para tratar do tema da Mesa levando em conta, ao mesmo tempo, a questão da controvérsia na abordagem do marxismo.

Achei importante discutir naquele momento o problema das interpretaçóes controvertidas porque estávamos num encontro de educadores marxistas. Ora, isso, no contexto atual, é uma espécie de avis rara. Somos um grupo pequeno e, mesmo assim, teimamos em nos dividir. Como fui colocado no centro da controvérsia, tornou-se oportuno fazer um esclarecimento prévio.

Não sou dado a exegese ou hermenêutica de textos. Por isso sempre me recusei a tomar um autor por ele mesmo e me debruçar sobre seus escritos tentando decifrá-los para expor o núcleo de seu conteúdo. Deixei isso claro quando em 1977 fui solicitado pelos alunos da primeira turma do doutorado em educação da PUC-SP a ministrar, no primeiro semestre de 1978, a disciplina optativa "Teoria da Educaçáo" com uma programação centrada no estudo monográfico da obra de Gramsci. Respondi que se tratasse de estudar Gramsci por Gramsci, não deviam contar comigo, mas se a ideia fosse estudar Gramsci para verificar em que grau ele pode nos ajudar a compreender nossa realidade e a enfrentar com mais consistência os problemas da educação brasileira, então, disse: nesse caso eu topo fazer esse estudo com vocês. Ou seja, eu me colocava na mesma posição em que eles se encontravam, isto é, sem maiores conhecimentos prévios do pensamento de Gramsci e me dispunha a participar desse esforço coletivo.

Em suma, recorro aos autores não para chegar à interpretação supostamente correta de seus textos na linha filológica ou hermenêutica. Nunca estudei os autores pelos autores. Recorro a eles para poder compreender melhor a realidade e responder aos problemas enfrentados. Assim, aqueles que 
se dedicam a esmiuçar os textos dos nossos autores de referência, se o fazem seriamente e no espírito da concepção dos referidos autores, são bem-vindos e vou agradecer a eles se me ajudarem a entender melhor os textos chaves e, mesmo, corrigir eventuais falhas de minha leitura. O problema é que, em geral, as cobranças que me são feitas justificadas pela exigência de uma leitura fiel de Marx, nuns casos, e de Gramsci, em outros, via de regra decorrem de leituras de gabinete, que se comprazem em confrontar textos (os meus) com textos (os dos autores de referência) quando o que importa, conforme a tese 2 de Marx sobre Feuerbach (MARX; ENGELS, 1982, p. 12), é confrontar os textos com a realidade.

Enfim, não me considero um especialista em Marx que estaria qualificado para a dissecação interna de seu pensamento com base na análise detalhada do conjunto de seus escritos. Por isso, só posso agradecer a quem resolve se dedicar a essa ingente tarefa.

\section{Educação, formação humana e ontologia: encaminhando a questão do método}

Feito esse esclarecimento preliminar, começo a exposição considerando o enunciado do próprio tema da Mesa, "Educação, formação humana e ontologia", para introduzir a discussão das dificuldades que temos de colocar em prática o método desenvolvido por Marx que conhecemos pelo nome de método histórico-dialético. Aliás, o lukacsiano Lucien Goldmann, ao tratar do pensamento dialético, já advertia: "trata-se evidentemente de um método mais difícil de realizar e de se fazer compreender do que o método analítico e linear do racionalismo, mas a ciência e a filosofia não conhecem caminhos fáceis, do mesmo modo que a vida e a ação" (GOLDMANN, 1967, p. 44). Álvaro Vieira Pinto (1969) lembrava que pensar dialeticamente não é apenas pensar as contradiçốes, mas pensar por contradição.

Tendo presente a mencionada dificuldade no manejo do método dialético, abordemos o referido tema da Mesa Redonda. Seu enunciado contém três conceitos: o primeiro é educação; o segundo, formação humana; e o terceiro é ontologia. Formalmente, esse enunciado se apresenta, de imediato, como problemático. Com efeito, os termos "educação" e "formação humana" são sinônimos. Portanto, a inclusão de ambos no enunciado de um mesmo tema resulta num pleonasmo. Ontologia, nós sabemos pelo estudo da filosofia, é o 
estudo do ser enquanto ser. Coincide, portanto, com a metafísica. Ora, como sabemos, trata-se de um campo da filosofia que não tem lugar no marxismo. Este se põe como crítica e superação da metafísica. No entanto, sabe-se que Lukács reabilitou a ontologia no âmbito do marxismo introduzindo a categoria "ontologia do ser social". Observo, de passagem, que no atual contexto marcado pela negação da objetividade própria da visão pós-moderna, essa reabilitação é bem-vinda, pois se faz necessário reafirmar resolutamente o caráter ontologicamente realista da concepção marxiana, assim como seu caráter gnosiologicamente objetivista. Continuando a análise, vemos que, do ponto de vista da linguagem, a expressão "ontologia do ser social" continua problemática. Isso porque se ontologia é o estudo do ser enquanto ser, então também a expressão "ontologia do ser social" resulta uma tautologia. Com efeito, se o conceito de ser já está contido no conceito de ontologia é redundante falar em ontologia do ser. Por esse raciocínio caberia concluir que, em lugar de ontologia do ser social, dever-se-ia falar em "ontologia do social".

No entanto, até aqui, a análise se moveu num plano formal. Esse tipo de análise náo é simplesmente descartável porque, como se sabe, a lógica dialética não nega a lógica formal por exclusão, mas a supera por incorporação. Dessa maneira, a lógica formal, embora válida, é claramente insuficiente. Antes de prosseguir devo dizer, entre parêntesis, que boa parte das críticas assacadas contra a pedagogia histórico-crítica, embora a acusem de formalismo, na verdade são as referidas críticas que padecem de formalismo. Espero, mais à frente, exemplificar essa afirmação.

Voltando ao enunciado do tema da Mesa, indo além da análise formal, é possível considerar que se educação e formação humana são sinônimos no plano formal, quando passamos ao plano concreto essa sinonímia já não é tão evidente. Com efeito, pode ocorrer que, no plano concreto, a educação se processe não como formação do homem, mas como sua deformação. A partir daí faz sentido distinguir os conceitos de educação e de formação humana conduzindo a análise na verificação do grau em que a educação, efetivamente, se configura ou não como um processo de formaçáo humana, análise essa que poderia eleger como critério para se distinguir entre a educação formadora e a deformadora do homem, aquilo que define o homem como tal, isto é, o que o constitui como ser humano; em suma, aquilo que caracteriza sua essência. Eis como se pode justificar a presença do terceiro termo, a ontologia, no enunciado do tema dessa Mesa. E o ser do homem, a sua essência, não é dada pela natureza, 
mas é produzida pelos próprios homens, processo esse que conhecemos pelo nome de trabalho.

O caminho que acabei de vislumbrar supóe, porém, a ultrapassagem da lógica formal e o manejo do método dialético e isso implica que a contradição, que a lógica formal repele, deva ser elevada, ela própria, ao status de categoria lógica.

Marx assim procedeu quando, no "método da economia política", descreveu o movimento que vai do empírico ao concreto pela mediação do abstrato, concluindo que o concreto, sendo unidade da variedade, síntese de múltiplas determinaçóes, é, para o pensamento, um resultado, o ponto de chegada e náo o ponto de partida, acrescentando, porém: "apesar de ser o verdadeiro ponto de partida e, portanto, igualmente o ponto de partida da observação imediata e da representaçâo" (MARX, 1973, p. 229 ).

À primeira vista essa passagem soa estranha, porque Marx afirma que o concreto náo é ponto de partida, é ponto de chegada. Mas, em seguida, desdiz o que havia dito afirmando que é o verdadeiro ponto de partida, frisando que antecede mesmo a própria observação imediata e a representação. Ou seja, está no ponto de partida das primeiras impressóes em que a realidade nos aparece como um todo caótico, sincreticamente.

Há, porém, um detalhe: o texto começa afirmando que o concreto é, para o pensamento, um resultado, ponto de chegada e náo ponto de partida. Esse aposto "para o pensamento" é fundamental, pois o que está em causa no referido texto é a distinçáo entre concreto real e concreto-de-pensamento.

O concreto real antecede o processo de conhecimento. É a base, o suporte sobre o qual se apoia todo o processo cognitivo. O pensamento que intenciona compreender o concreto real começa pela observação imediata, procede à sua análise fazendo intervir as categorias simples num processo de abstração podendo, de posse desses elementos, retornar ao todo reproduzido, agora como concreto-de-pensamento enquanto síntese de relações e determinações numerosas.

A lógica formal se detém no momento analítico e abstrato, promovendo as distinçóes dos vários aspectos e enunciando na forma das categorias simples, isto é, os elementos do objeto estudado. Pela lógica dialética esse momento é superado, sendo recuperado o concreto real agora compreendido e enunciado teoricamente em toda a sua complexidade. 
Dou apenas mais um exemplo do manejo do método dialético me reportando ao texto "Introdução à crítica da economia política" em que Marx (1973) analisa o processo de produção. O autor mostra que o processo global da produção compreende as relaçóes entre a produção propriamente dita, que constitui o geral, a distribuição e a troca, que representam o particular, e o consumo, que corresponde ao singular, como termo final que é a razão de ser de todo o processo de produção. Assim caracterizados, a produção, a distribuição, a troca e o consumo formam "um silogismo modelo".

A produçáo constitui o ponto de partida (termo maior), o consumo o ponto de chegada (termo menor), comportando-se, assim, a distribuição e a troca como o termo médio, com um duplo caráter: a distribuição se origina da sociedade e a troca do indivíduo. Na produção os homens ajustam os recursos da natureza às suas necessidades humanas; pela distribuiçẫo a sociedade determina a participação proporcional dos indivíduos na repartição dos produtos; através da troca cada indivíduo obtém os produtos particulares, nos quais decide converter a quota-parte que lhe foi determinada pela distribuição; e, por fim, no ato do consumo os produtos se tornam objetos de apropriaçáo individual e de fruiçáo. Dizendo de outra forma, nos termos do próprio Marx:

A produção cria os objetos que correspondem às necessidades; a distribuição reparte-os segundo leis sociais; a troca reparte de novo o que já tinha sido repartido, mas segundo as necessidades individuais; no consumo, enfim, o produto evade-se desse movimento social, torna-se diretamente objeto e servidor da necessidade individual, que satisfaz pela fruição. (MARX, 1973, p. 217).

Marx (1973) assinala que esse silogismo modelo representa, sim, um encadeamento lógico, "mas muito superficial". E, aprofundando a análise, nos mostra que a produção é imediatamente consumo: é consumo das energias do trabalhador, de meios de produçáo, de matéria-prima. Portanto, "o ato de produçáo é, em todos os seus momentos e ao mesmo tempo, um ato de consumo [...]" (MARX, 1973, p. 218) - "consumo produtivo". O consumo, por sua vez, é também produção, pois toda espécie de consumo contribui, de uma maneira ou de outra, para a produçáo humana. Por exemplo, pelo alimento que o trabalhador consome, ele produz seu próprio corpo - "produçáo consumidora" 
- e recupera as energias que serão novamente consumidas na produção.

Marx ultrapassa a lógica formal, manejando os conceitos próprios da lógica dialética, ao concluir:

Portanto, a produçáo é imediatamente consumo, o consumo imediatamente produçáo. Cada um é imediatamente o seu contrário. Mas opera-se simultaneamente um movimento intermediário entre os dois termos. A produção é a intermediária do consumo, a quem fornece os elementos materiais e que, sem ela, não teria qualquer objetivo. Por seu lado, o consumo é também o intermediário da produção, dando aos produtos o motivo que os justifica como produtos. Só no consumo o produto conhece a sua realização última. (MARX, 1973, p. 219).

Há, pois, uma unidade entre o consumo e a produção que se manifesta num triplo aspecto:

$1^{\circ}$ Identidade imediata. A produção é consumo; o consumo é produção. Produçẫo consumidora. Consumo produtivo [...].

$2^{\circ}$ Ambos surgem como intermediários um do outro; uma é intermediada pelo outro, o que se exprime pela sua interdependência, movimento que os relaciona entre si e os torna reciprocamente indispensáveis, embora se conservem exteriores uma ao outro. [...]. Sem produção não há consumo; sem consumo não há produção [...].

$3^{\circ}$ A produçáo não é apenas imediatamente consumo, nem o consumo imediatamente produção; igualmente a produção não é apenas um meio para o consumo, nem o consumo um fim para a produção [...]. Cada um, ao realizar-se, cria o outro; cria-se sob a forma do outro. (MARX, 1973, p. 221, grifo no original).

Em suma, o que está em causa é o entendimento do processo de produção social como uma totalidade, cuja unidade se expressa nos momentos específicos de produção, distribuição, troca e consumo. Marx expressa esse entendimento 
nos seguintes termos: "Não chegamos à conclusão de que a produção, a distribuição, a troca e o consumo são idênticos, mas que são antes elementos de uma totalidade, diferenciaçóes no interior de uma unidade [...]" (MARX, 1973, p. 227). E arremata: "Há reciprocidade de ação entre os diferentes momentos. O que acontece com qualquer totalidade orgânica". (MARX, 1973, p. 228).

Retomemos o lembrete de Álvaro Vieira Pinto (1969): pensar dialeticamente não é apenas pensar as contradições, mas é pensar por contradição. Essa é a forma de pensar de Marx. Essa é a exigência do método de Marx, o método dialético.

Sendo assim, parece que não há nada menos marxista do que ler os textos de Marx de maneira formal e, além disso, mutilando seu conteúdo. Da minha parte, tenho me esforçado em lê-lo tendo presentes as exigências do método que presidiu à sua elaboração teórica. Sobretudo, tenho procurado sempre guiar-me pela tese 2 de Marx, sobre Feuerbach, assim formulada:

A questão de saber se cabe ao pensamento humano uma verdade objetiva não é uma questão teórica, mas prática. É na práxis que o homem deve demonstrar a verdade, isto é, a realidade e o poder, o caráter terreno de seu pensamento. A disputa sobre a realidade ou não-realidade do pensamento isolado da práxis - é uma questão puramente escolástica. (MARX, 1982, p. 12).

Sou obrigado, no entanto, a constatar que a controvérsia levantada nesse nosso pequeno grupo de educadores marxistas resvala para a "questão puramente escolástica", sendo guiada por um formalismo lógico que não se reconhece como tal e, por isso, acusa paradoxalmente os adeptos da pedagogia histórico-critica de incidir no referido formalismo.

O que disse pode ser ilustrado pela crítica que Sérgio Lessa (2007) me endereça ao discutir a questáo da relação entre trabalho e educação. Em que pese o esforço louvável de introduzir precisóes terminológicas pela via da análise interna de textos de Marx, como Gaudêncio Frigotto já havia assinalado, Lessa trabalha "mais com antinomias do que com a contradição." (FRIGOTTO, 2009, p. 179). Ele parte de meu texto Sobre a natureza e especificidade da educação (LESSA, 2007) para afirmar que, se eu considero o trabalho como princípio fundante da educação eu não poderia, mais à frente, afirmar que a educação também é trabalho. Ora, diz ele: 
Identificado fundante e fundado, esta relaçáo pela qual uma categoria funda a outra é substituída pela relação de identidade. A identidade não pode ser portadora da relação fundado/fundante [...]. Se a educação é trabalho, não se pode mais dizer que este é fundante daquela [...]". (LESSA, 2007, p. 107).

Claro. É assim porque ele está manejando o princípio de identidade, próprio da lógica formal, e não o princípio de contradição que rege a lógica dialética. Por esse raciocínio de Lessa (2007), Marx não poderia dizer que o consumo é também produção. Com efeito, se a produção é a base, o fundamento do consumo, como o fundado pode se identificar com o fundante? Acontece que Marx está operando dialeticamente com as categorias de contradição e de ação recíproca. Por isso ele pode dizer que a produção é consumo e vice-versa, o que implica que a produção determina o consumo e o consumo determina a produção. Foi com base nessa mesma lógica que analisei a relação entre trabalho e educação.

E aqui podemos retomar o tema da Mesa: educação, formaçáo humana e ontologia. Considerando que é o trabalho que define a essência humana, podemos considerar que está aí a referência ontológica para se compreender e reconhecer a educação como formação humana. O homem se constitui como homem, ou seja, se forma homem no e pelo trabalho. Esse processo de produção do homem que coincide com seu processo de formação vai se complexificando ao longo da história dando origem a diversas modalidades de trabalho, entre as quais assume particular relevância a diferenciação entre trabalho manual e intelectual ou entre trabalho material e não-material. Cada uma dessas duas grandes divisōes, por sua vez, se diferencia internamente decorrendo diversas modalidades específicas de trabalho. Eis porque se pode falar em trabalho rural ou agrícola, trabalho industrial ou fabril, trabalho comercial etc. E, igualmente, em trabalho musical, trabalho literário, trabalho político, trabalho parlamentar, trabalho administrativo e trabalho educativo ou trabalho pedagógico. Então, educação também é trabalho. Por que não? Mas isso não significa, como pensou Sérgio Lessa (2007), que se estaria simplesmente identificando trabalho e educaçáo. Nesse ponto é possível parafrasear Marx quando considerou que "não chegamos à conclusão de que a produção, a distribuição, a troca e o consumo são idênticos, mas que são antes elementos de uma totalidade, diferenciações no interior de uma unidade" (MARX, 1973, p. 227), afirmando: náo chegamos à 
conclusão de que trabalho e educação são idênticos, mas que são antes elementos de uma totalidade, diferenciaçôes no interior de uma unidade, concluindo com ele: "há reciprocidade de ação entre os diferentes momentos. O que acontece com qualquer totalidade orgânica" (MARX, 1973, p. 228). Estão aí, aplicadas por Marx explicitamente, as categorias dialéticas da totalidade, contradição e ação recíproca.

\section{Esclarecendo as controvérsias}

Considerando essa centralidade da categoria "trabalho" na teoria marxista é compreensível que a controvérsia instaurada pelo grupo que vem insurgindo contra a pedagogia histórico-crítica em nome do marxismo gire basicamente em torno dela. Grosso modo, as críticas assumem as seguintes modalidades:

Primeira modalidade crítica: formulam objeçóes e detectam insuficiências e equívocos atribuídos à pedagogia histórico-crítica e, especificamente, a mim que, no entanto, deveriam se dirigir às próprias matrizes teóricas do marxismo, vale dizer, a Marx e a Gramsci.

Ilustremos com dois exemplos essa modalidade de crítica.

10 exemplo:

Estou sendo criticado por considerar a distinção entre produção material e não-material e, dentro desta última, a diferenciação entre a produção nãomaterial cujo produto se separa do produtor e a aquela em que o produto náo se separa do produtor. Afirma-se que coloco essa distinção em lugar da distinção formulada por Marx entre trabalho produtivo e improdutivo.

Ora, essa objeção não deve ser dirigida a mim, mas ao próprio Marx, pois é ele quem faz as referidas distinçóes textualmente no Capitulo VI inédito de $O$ Capital (MARX, 1978) ${ }^{1}$. Esse equívoco - para usar uma palavra que esses críticos gostam de me atribuir - é compreensível em Sérgio Lessa (2007) por dois motivos: a) ele deliberadamente se centra no Livro I de O Capital (MARX, 1983; 1985) e exclui ou secundariza os demais, inclusive o Capítulo $V I$ - inédito ${ }^{2}$; b) ele toma como referência meu texto Sobre a natureza e especificidade da educação (SAVIANI, 2000), no qual trabalho com a distinção entre produção material e produção não-material, mas não cito diretamente Marx remetendo a meu texto anterior Trabalhadores da educação e crise na universidade, no qual se encontra a citação e que havia sido publicado em 1984 no livro Ensino público e algumas 
falas sobre universidade.

Lazarini (2010), porém, inclui na bibliografia de sua tese de doutorado o Capítulo VI - inédito de Marx, e também meu livro Ensino público e algumas falas sobre universidade (SAVIANI, 1984) mencionando, explicitamente o texto Trabalhadores da educação e crise da universidade. Resulta incompreensível, então, o motivo pelo qual ele procede, como se a distinção entre produção material e produção não-material tivesse sido inventada por mim.

Como Lazarini (2010), de fato, apenas repete a crítica de Lessa (2007) emerge uma indagação que não quer calar: será que, mesmo tendo conhecimento de meu texto ele achou dispensável fazer a leitura do mesmo e igualmente também não se deu ao trabalho de ler o tópico do Capítulo VI - inédito denominado Trabalho produtivo e improdutivo, no interior do qual Marx faz a diferença entre produção material e não material e distingue, dentro desta última, as duas modalidades que já mencionei? Talvez seja a não leitura do conteúdo desse tópico que o levou a considerar que eu inventei a referida distinção distanciando-me de Marx que trabalharia com a distinção entre trabalho produtivo e improdutivo. Será que ele leu o título do tópico, mas não achou necessário ler seu conteúdo? Daí, a denúncia bombástica estampada no item 3.5.2. de sua tese de doutoramento: "a educação como 'trabalho nãomaterial': simbiose entre idealismo e empirismo sensitivo" (LAZARINI, 2010). Diante dessa constatação, cabe a seguinte ironia: Pobre do nosso Marx! Tão limitado intelectualmente que acabou sendo vítima da simbiose entre idealismo e empirismo sensitivo!

$2^{\circ}$ exemplo:

Do mesmo tipo é a questão do trabalho como princípio educativo. Imputa-se aos defensores da pedagogia histórico-crítica a formulação e a defesa dessa tese que, no entanto, foi formulada por Gramsci. Então, esses críticos deveriam voltar-se contra o próprio Gramsci afirmando que ele cometeu um enorme equívoco porque ter-se-ia afastado de Marx e do marxismo quando escreveu suas notas do cárcere, nomeando o $\$ 2^{\circ}$ do Caderno 12 com o título Observaçóes sobre a escola: para a investigação do princípio educativo, no qual afirma que "o conceito e o fato do trabalho (da atividade teórico-prática) é o princípio educativo imanente à escola elementar, dado que a ordem social e estatal (direitos e deveres) é introduzida e identificada na ordem natural pelo trabalho" (GRAMSCI, 1975, p. 1541). E ele não estava falando de uma escola futura, pois essa citação foi precedida pela seguinte consideração: 
Pode-se dizer que o princípio educativo que fundava as escolas elementares era o conceito de trabalho, que náo pode realizar-se em toda a sua potência de expansão e de produtividade sem um conhecimento exato e realístico das leis naturais e sem uma ordem legal que regule organicamente a vida dos homens entre si, ordem que deve ser respeitada pela convicção espontânea e não somente por imposição externa, por necessidade reconhecida e proposta a si próprios como liberdade e não por mera coerção. (GRAMSCI, 1975, p. 1541).

Gramsci vai mais além afirmando:

É necessário convencer a muita gente que também o estudo é um trabalho, e muito cansativo, com um seu especial tirocínio, além de intelectual, também muscularnervoso: é um processo de adaptação, é um hábito adquirido com esforço, aborrecimento e também com sofrimento. (GRAMSCI, 1975, p. 1549).

Segunda modalidade de crítica: cita-se uma frase minha declarando-a indicadora de equívocos e passa-se a discorrer sobre Marx para supostamente demonstrar que me afasto do marxismo, mas ou não ocorre a demonstração do tal afastamento ou a frase é mais uma imputação do que a expressão de minha posição.

Ilustremos essa segunda modalidade com quatro exemplos.

10 exemplo:

No texto de Ivo Tonet (2010), Educação e revolução, publicado em Germinal: Marxismo e Educaçáo em Debate, no qual sou mencionado em meio a treze outros autores aos quais se atribui o seguinte entendimento: "para todos esses autores, o pressuposto de sua elaboração era, de algum modo, a ideia de que a revolução soviética tinha sido uma revolução de caráter socialista e de que o caminho trilhado por ela, não obstante todos os percalços, continuava a ser socialista”. (TONET, 2010, p. 46).

Pela parte que me toca, isso não passa de mera imputação sem apoio em qualquer um de meus trabalhos. Ao contrário, em várias oportunidades 
me manifestei sobre os limites da experiência soviética, desde a frustração da expectativa de Lênin de que a revolução russa fosse o primeiro elo de uma cadeia mundial de revoluçóes proletárias à qual se seguiriam os principais países capitalistas da Europa, começando pela Alemanha e Itália até as análises que lhe atribuíam à denominação de capitalismo de Estado. É preciso deixar claro: uma coisa é levar em conta as tentativas de revolução socialista e procurar analisá-las para compreender as dificuldades, limites e problemas; e outra coisa é considerar que determinada experiência, neste caso a da revolução soviética, tenha sido não apenas uma revolução de caráter socialista, mas que trilhou um caminho, de fato, socialista. Também náo procede a imputação de que eu estaria defendendo um "caminho democrático para o socialismo". Minhas críticas à democracia burguesa têm sido contundentes e constantes.

Portanto, todo o texto foi construído sobre um pressuposto se não falso, pelo menos discutível. Assim, as consideraçóes que, em boa parte, eu poderia encampar relativas ao problema do deslocamento da centralidade do trabalho para a centralidade da política são apresentadas como se tivessem o condão de desfazer minha ilusão ou meu equívoco sobre o caráter da revolução soviética que teria conduzido a teoria pedagógica para a centralidade da política com a consequente defesa do caminho democrático para o socialismo.

2o exemplo:

Sobre essa mesma questão da suposta defesa da democracia e do Estado burguês incide a crítica de Lazarini (2010) que invoca, para tanto, a "Crítica ao Programa de Gotha”. Afirma ele que eu defendo que a pedagogia históricocrítica possa ser adotada como política educacional do Estado capitalista e recorre à crítica de Marx ao Estado prussiano. Ora, em 1980 organizei um simpósio na I CBE tendo por tema "Repondo a questáo da defesa da escola pública no Brasil hoje”. E minha exposição nesse simpósio teve por título "Uma estratégia em defesa da escola pública: retirar a educação da tutela do Estado" centrando minha argumentação exatamente na "Crítica ao Programa de Gotha". Depois, incluí esse texto no livro Ensino público e algumas falas sobre universidade (SAVIANI, 1984), com o título simplificado de $A$ defesa da escola pública. Como Lazarini (2010) menciona esse livro, fica a seguinte indagação: será que ele leu apenas o título e, com isso, deixou de atentar para minha argumentação centrada no texto de Marx inferindo, consequentemente, que se eu estava defendendo a escola pública, então estava sob a órbita do Estado capitalista? 
3o exemplo:

De teor semelhante é o texto de Paulo Sérgio Tumolo publicado primeiro em 2003 numa revista eletrônica da UFF com o título "O significado do trabalho no capitalismo e o trabalho como princípio educativo: ensaio de análise crítica" e, em 2005, na Revista Educação \& Sociedade com o título "O trabalho na forma social do capital e o trabalho como princípio educativo: uma articulação possível?". Aí também o autor coloca em questão o que ele chama de lema do trabalho como princípio educativo e toma como referência a citação de uma passagem minha na qual afirmo que "todo sistema educacional se estrutura a partir da questáo do trabalho" (SAVIANI, 1986, p. 14 apud TUMOLO, 2005, p. 241), considerando-a como supostamente representativa de uma corrente integrada por vários autores que ele apenas menciona. Em seguida, passa a efetuar a exegese do conceito de trabalho em $O$ Capital, de Marx. E não retorna mais à citação de meu texto, dando a impressão de que a menção foi apenas um pretexto para se debruçar sobre o sentido do conceito de trabalho em $O$ Capital.

Em princípio não tenho propriamente objeçóes à análise exegética efetuada sobre o conceito de trabalho em Marx. Com base em sua análise, Tumolo (2005, p. 256) irá concluir pela negação de que o trabalho possa ser princípio educativo de "[...] uma estratégia político-educativa que tenha como horizonte a transformação revolucionária da ordem do capital". Ele também nega que mesmo numa sociedade já emancipada o trabalho possa ser princípio educativo, e nessa nova forma social "[...] talvez o prazer seja princípio educativo e não o trabalho" (TUMOLO, 2005, p. 256). Essa conclusão é surpreendente porque ele próprio havia afirmado, com base em Marx, que a produção de valores de uso "[...] náo tem, em princípio, um caráter capitalista, uma vez que tal relaçáo é condição eterna da humanidade para produzir sua vida em qualquer forma societal" (TUMOLO, 2005, p. 247). Por que então numa sociedade emancipada o trabalho perde relevância deslocando o princípio educativo para o prazer?

Cabe lembrar, aqui, as análises de Marx (1968, p. 109) nos Manuscritos Econômico-Filosóficos em que ele chama atenção para o fato de que, sob o capitalismo, o trabalho, atividade constitutiva da própria essência humana, se manifesta de tal forma que o homem não encontra nele fonte de realização, mas de sofrimento ao passo que ele vai se sentir realizado nas atividades que ele tem em comum com os animais: comer, beber e procriar. Essa é a condição do trabalho alienado. 
Diante disso, é de se supor que na sociedade emancipada o trabalho deixará de ser alienado e, consequentemente, de ser fonte de sofrimento e passará a ser fonte de realização, ou seja, fonte de prazer. Enfim, o trabalho não apenas continuará a ser princípio educativo, mas será o princípio educativo de uma humanidade que se reconciliou consigo mesma e, portanto, realizará sem sofrimento a condiçâao eterna de produçáo de sua própria vida. E os homens se realizarão, sentirão prazer no trabalho e não apenas na comida, na bebida e no sexo.

$4^{\circ}$ exemplo:

O sumário da tese de Lazarini (2010), todo recheado de denúncias bombásticas, contém mais as seguintes pérolas: Item 3.3 "As ilusôes de Saviani acerca da aplicação de tecnologia de base microeletrônica à produção capitalista contemporânea: uma compreensão fetichista da reestruturação produtiva e suas consequências para as teorizaçóes educacionais"; prossegue no item 3.3.2 "Sobre as 'virtualidades' da polivalência toyotista e da tecnologia de base microeletrônica para formação dos trabalhadores: ilusóes de Saviani e notas críticas a elas a partir da análise de estudos diversos e de pesquisas de campo"; e reitera no item 3.3.3 "Notas sobre a relação entre reestruturação produtiva de base microeletrônica e educação formal: alguns questionamentos às assertivas matriciais de Saviani”.

$\mathrm{Na}$ verdade no texto que ele cita para respaldar essas denúncias, não trato da reestruturação produtiva. Trato, sim, da revolução micro-eletrônica. E o que está destacado ali é a questão do avanço das forças produtivas e sua contradição com as relaçôes de produção. Registro que o avanço das forças produtivas, expresso nos resultados da Revolução Micro-Eletrônica, permitiu o amadurecimento das condiçóes objetivas para a emancipação, ou seja, com a introdução em larga escala da automaçáo no processo produtivo os homens estariam em condiçóes de produzir tudo o que é necessário para a humanidade viver confortavelmente com um mínimo de dispêndio das energias dos trabalhadores. Mas isso não pode se efetivar porque as relaçóes de produção baseadas na propriedade privada dos meios de produção impedem. Esse destaque ao avanço das forças produtivas ensejou a Lazarini de me acusar de fetichismo tecnológico e de entusiasta das novas tecnologias. Ora, em todas as oportunidades que me apresentaram sempre me manifestei criticamente em relação a essa adesão pré-crítica, generalizada às novas tecnologias na sociedade em geral e na educação de modo particular. É preciso distinguir entre a positividade do avanço tecnológico, que Marx destacou insistentemente, e a serviço de quem esse avanço é posto nas condiçóes 
próprias da sociedade capitalista. Ou será que Lazarini vai sair por aí incitando à destruição dos computadores e todo o complexo das máquinas eletrônicas como fizeram os operários com as máquinas a vapor introduzidas nas fábricas por ocasião da Primeira Revolução Industrial?

Mas, segundo Lazarini (2010), minhas ilusóes não se limitam às novas tecnologias. Estendem-se também à polivalência toyotista. Se ele se propôs a fazer uma tese sobre o conjunto de minha obra, não compreendo por que ele não leu as críticas reiterativas que tenho feito à chamada acumulação flexível, ao toyotismo, à qualidade total. Isso aparece em várias entrevistas, artigos e foi contemplada no último capítulo do livro "História das ideias pedagógicas no Brasil", lançado em 2007. Aí, sim, levo em conta o fenômeno da reconversão produtiva.

Ele, porém, é incansável na determinação iracunda de avançar em suas denúncias. E chega ao clímax na p. 389 de sua tese quando, impregnado de indignação moral afirma: "o pior ainda estava por vir" (LAZARINI, 2010) e cita esta passagem de um de meus textos: "Se esse desafio permanecer sem resposta, as metas proclamadas de modernização tecnológica, incremento de produtividade e ingresso no Primeiro Mundo não passarão de promessas blandiciosas." (SAVIANI, 2003b, p. 166 apud LAZARINI, 2010, p. 75, grifo do autor). E Lazarini vai em frente qual D. Quixote a destruir moinhos de vento buscando elementos e trazendo dados para mostrar o absurdo daquela minha afirmação. Traz em seu apoio a tese de doutoramento de sua orientadora de mestrado, Zélia Leonel, acreditando estar me transmitindo preciosas lições, não se advertindo de que precisamente aquela tese foi orientada por mim. Mas ele segue adiante, insurgindo-se contra a expressão "primeiro mundo", constatando que sou adepto da "surrada e falaciosa" divisão dos países em primeiro, segundo e terceiro mundos. Meu livro "Educação: do senso comum à consciência filosófica", publicado em 1980, consta na bibliografia de sua tese e é citado em uma ou outra passagem, quando lhe convém. Mas ou ele não o leu todo ou se esqueceu que em dois textos incluídos nesse livro faço a crítica desse tipo de concepção (SAVIANI, 1980). Mas então, por que enunciei uma frase tão absurda?

Um aspecto que tende a passar despercebido aos críticos é que meus textos, via de regra, são textos de combate. As discussóes teóricas não são feitas por si mesmas. Minha referência constante, como já assinalei, é a tese 2 sobre Feuerbach (MARX, 1982). Por isso, normalmente, minhas discussóes 
teóricas tendem a desembocar no problema prático ligado ao como conduzir nossas lutas. E nesse embate por vezes recorro a argumentos "ad hominem" ou à ironia. Foi esse recurso que utilizei nessa referência aos empresários. Falo aí em "metas proclamadas". Proclamadas por quem? Pelos empresários e seus representantes e porta-vozes. São eles que vivem a proclamar a necessidade da modernização tecnológica, incremento da produtividade e ingresso no Primeiro Mundo. Então, lancei-lhes essa provocação: se o desafio da construçáo de um sistema educacional consistente não tiver resposta, suas proclamações não passarão de promessas blandiciosas. A ironia consiste em que lancei máo de uma expressão do general Golbery do Couto e Silva no livro Geopolitica do Brasil, no tópico denominado "O Brasil precisa do Ocidente", que encerra com essas frases: "Redimindo os povos irmãos desta América, o Ocidente redimiria, pela esperança, os povos todos da Terra. $\mathrm{E}$ as sereias comunistas cantariam ao vento insensível suas promessas blandiciosas..." (SILVA, 1981, p. 249). Com essa ironia, quis evidenciar a contradição entre o discurso valorizador da educação por parte dos empresários e da classe dominante de modo geral e sua desvalorização prática. Não percebendo a ironia, Lazarini (2010, p. 397) afirma que meus termos não deixam dúvidas quanto à minha aceitação das teses que afirmam "existirem 'países desenvolvidos' e 'países em desenvolvimento' e que os últimos estão a caminho dos primeiros”. E decreta o anátema afirmando que aceito essas teses "[...] da maneira mais superficial e mistificadora" (LAZARINI, 2010, p. 397-398).

Terceira modalidade das críticas cujo móvel é a negação da escola.

Aqui quero apenas manifestar minha estranheza com essa atitude diante da educação escolar por parte de intelectuais da educação que se dizem marxistas. De onde vem essa repulsa? Por certo não é de Marx, muito menos de Lênin ou de Gramsci. Com certeza já foi lembrado em outras Mesas do mesmo V EBEM que Marx e Engels inscreveram no Manifesto do Partido Comunista, como medida que devia ser implantada, a educaçáo pública e gratuita de todas as crianças. Também certamente foram lembradas as "Instruçóes" de Marx aos delegados da Associação Internacional dos Trabalhadores que registrava como conclusão que a união entre trabalho produtivo remunerado, ensino intelectual, exercício físico e formaçáo politécnica elevará a classe operária muito acima das classes superiores e médias, retomada em $O$ Capital na forma da união entre trabalho produtivo, ensino e ginástica como o único método para produzir homens plenamente desenvolvidos (vejam aí a educação entendida como produtora de 
homens plenamente desenvolvidos. E então, não é trabalho?). Bem, eu poderia prosseguir mencionando a "Crítica ao Programa de Ghota" e passar às várias falas de Lênin e às notas de Gramsci. Mas isso é desnecessário porque se trata de textos bastante conhecidos no campo marxista.

Assim, mantém-se a estranheza que, na verdade, cresce bem mais quando constatamos que esses nossos colegas fizeram todo o percurso escolar, passando por todas as etapas da educaçáo básica e da educação superior (graduação, mestrado e doutorado) e se encontram atuando exatamente em instituições escolares, dominantemente em universidades.

\section{Concluindo}

Meu esforço em construir uma teoria pedagógica fundamentada no marxismo decorreu da insatisfação com os textos que abordavam a educação nessa perspectiva, já que uma teoria marxista da educação e principalmente uma pedagogia marxista não chegava a emergir dessas análises. Diante disso, em lugar de gastar papel e tinta criticando esses autores por essa insuficiência, optei por me apoiar em seus elementos indiciários e, especialmente, em seu percurso pelos clássicos do marxismo para procurar elaborar a teoria de que sentia necessidade. De certo modo, seguindo a indicaçáo de Marx, considerei-os gigantes e apoiei-me sobre seus ombros para ver e chegar mais longe. Foi com esse espírito que levei em conta as contribuiçóes de autores como Suchodolski, Manacorda, Snyders, Pistrak, Makarenko. É desse esforço que resultaram as formulaçôes nomeadas de pedagogia histórico-crítica que está em construção e não é obra exclusivamente minha. Trata-se de uma iniciativa limitada, lacunosa, que contém equívocos? Assim sendo, as críticas capazes de apontar esses problemas serão bem-vindas. Essa teoria pedagógica pode ou deve ser superada? Se este for o caso, que o seja no espírito da concepção do materialismo histórico que implica a superação por incorporação. Não parece uma atitude coerente com essa concepção a mera negação da proposta pedagógica que se está procurando construir.

\section{Notas}

${ }^{1}$ A passagem em questão é a seguinte: "No caso da produção não material, ainda que esta se efetue exclusivamente para a troca e produza mercadorias, existem duas possibilidades: a) $\mathrm{O}$ resultado são mercadorias que existem 
isoladamente em relação ao produtor, ou seja, que podem circular como mercadorias no intervalo entre a produção e o consumo; por exemplo: livros, quadros, todos os produtos artísticos que se diferenciam da atividade artística do artista executante. A produção capitalista só se aplica aqui em forma muito limitada. Essas pessoas, sempre que não se contratem oficiais etc., na qualidade de escultores etc., comumente (salvo se forem autônomos) trabalham para um capital comercial, como, por exemplo, livreiros, uma relação que constitui apenas uma forma de transição para o modo de produção apenas formalmente capitalista. Que nessas formas de transição a exploração do trabalho alcance um grau superlativo, não altera a essência do problema. b) O produto não é separável do ato de produção. Aqui, também, o modo capitalista de produção só tem lugar de maneira limitada, e pela própria natureza da coisa não se dá senão em algumas esferas. (Necessito do médico, não de seu moleque de recados). Nas instituiçóes de ensino, por exemplo, os docentes podem ser meros assalariados para o empresário da fábrica de conhecimentos. Não se deve considerar o mesmo para o conjunto da produção capitalista”. (MARX, 1978, p. 79).

${ }^{2}$ Sobre as "graves implicações e riscos que podem conduzir a tergiversações e à parcialidade de um pensador ou de toda uma corrente de pensamento científico" decorrentes da análise de Lessa (2007), que se limita apenas "aos capítulos V e XIV do Livro I, sem abordar os Livros II e III de O Capital e, por suposto, também o Capitulo VI - Inédito", veja-se a crítica rigorosa do sociólogo mexicano Adrián Sotelo (2009), professor da Universidade Nacional Autônoma do México.

\section{REFERÊNCIAS}

DUARTE, Newton et al. A pedagogia histórico-crítica e o marxismo: equívocos de (mais) uma crítica à obra de Dermeval Saviani. Revista HISTEDBR Online, Campinas, SP, número especial, p. 38-57, abr. 2011.

FRIGOTTO, Gaudêncio. A polissemia da categoria trabalho e a batalha das ideias nas sociedades de classe. Revista Brasileira de Educação, Rio de Janeiro, v. 14, n. 40, p. 168-194, jan./abr. 2009.

GOLDMANN, Lucien. Dialética e cultura. Rio de Janeiro: Paz e Terra, 1967. 
GRAMSCI, Antonio. Quaderni del cárcere. Torino: Einaudi, 1975. 3v. (Edizione critica dell'Istituto Gramsci a cura di Valentino Gerratana).

LAZARINI, Ademir Quintilio. A relação entre capital e educação escolar na obra de Dermeval Saviani: apontamentos críticos. 2010. 532 p. Tese (Doutorado em Educação) - Universidade Federal de Santa Catarina. Florianópolis, SC, 2010.

LESSA, Sérgio. Trabalho e proletariado no capitalismo contemporâneo. São Paulo: Cortez, 2007.

MARX, Karl. Manuscritos: economia y filosofia. Madrid: Alianza Editorial, 1968.

MARX, Karl. Contribuição para a crítica da economia política. Lisboa: Estampa, 1973.

MARX, Karl. O Capital. Livro I. São Paulo: Abril Cultural, 1983 (Tomo I), 1985 (Tomo II).

MARX, Karl. O Capital, Livro I, Capitulo VI (inédito). São Paulo: Ciências Humanas, 1978.

MARX, Karl. Teses sobre Feuerbach. In: MARX, Karl; ENGELS, Friedrich. A ideologia alemã. 3. ed. São Paulo: Ciências Humanas, 1982.

PINTO, Álvaro Vieira. Ciência e existência. Rio de Janeiro: Paz e Terra, 1969.

SAVIANI, Dermeval. Educação: do senso comum à consciência filosófica. São Paulo: Cortez, 1980.

SAVIANI, Dermeval. Ensino público e algumas falas sobre universidade. São Paulo: Cortez, 1984.

SAVIANI, Dermeval. Sobre a natureza e especificidade da Educação. In: SAVIANI, Dermeval. Pedagogia histórico-crítica, $7^{\text {a }}$ ed. Campinas, Autores Associados, 2000, p. 15-28.

SILVA, Golbery do Couto e. Conjuntura politica nacional: o poder executivo \& Geopolítica do Brasil. 3. ed. Rio de Janeiro: José Olympio, 1981.

SOTELO, Adrián. Trabalho, classe trabalhadora e proletariado: ensaios sobre as contradiçóes e as crises do capitalismo contemporâneo. Revista Serviço 
Social \& Sociedade, São Paulo, n. 97, p. 178-194, jan./mar. 2009.

TONET, Ivo. Educação e revolução. Germinal: Marxismo e Educação em Debate, Londrina, PR, v. 2, n. 2, p. 43-53; ago. 2010.

TUMOLO, Paulo Sérgio. O trabalho na forma social do capital e o trabalho como princípio educativo: uma articulação possível? Educação \& Sociedade, Campinas, SP, v. 26, n. 90, p. 239-265, jan./abr. 2005. 
Debate sobre las relacciones entre educación, formación humana y ontología a partir del método dialéctico

\section{Resumen}

El tema "Educación, formación humana y ontología” es abordado a partir del método dialéctico y en articulación con el problema de las controversias en el campo marxista motivado por la tesis de doctorado La relación entre capital y educación escolar en la obra de Dermeval Saviani: notas críticas (A relação entre capital e educação escolar na obra de Dermeval Saviani: apontamentos críticos). Partiendo del método de conocimiento desarrollado por Marx se considera el significado del tema referente a la relación entre educación, formación humana y ontología respondiendo, en la secuencia, a algunas de las objeciones formuladas en el ámbito de la controversia producida por la mencionada tesis de doctoramiento. En la construcción del texto se procedió a una argumentación distribuída en cuatro momentos. Despues de una introducción situando la emergencia del debate se expone, en un segundo momento, el significado del método dialéctico tomando como referencia la formulación teórica de Marx. El tercer momento es dedicado a la aclaración de las controversias ilustradas por medio de algunos
Debate about the relations among education, human development and ontology based on the dialectic method

\begin{abstract}
The theme "Education, human development and ontology" is approached from the dialectic method and in articulation with the problem of the controversies in the Marxist field motivated by the Doctoral Thesis A relação entre capital e educação secular na obra de Dermeval Saviani: apontamento críticos (The relation between capital and secular education in the work of Dermeval Saviani: critical comments). From the method of analysis developed by Marx, the paper considers the meaning of the theme regarding the relations between education, human development and ontology, and then responds to some of the objections formulated in that doctoral thesis. The argument is divided in four parts. The introduction situates the emergence of the debate and the second part discusses the significance of the dialectic method using Marx's theoretical formulation as a reference. The third part is dedicated to clarifying some debates, illustrated by some examples. The brief conclusion highlights the nature of the criticalhistorical pedagogy as theory of education formulated in agreement
\end{abstract}


ejemplos. Finalmente, en una breve conclusión, se destaca el carácter de la pedagogía histórico-crítica como teoría de la educación formulada en consonancia con el materialismo histórico.

Palabras claves: Marxismo y educación. Abordaje dialéctico de la educación. Controversias marxistas. with historical materialism.

Keywords: Marxism. Historical-critical approach. Educational debate.

\section{Dermeval Saviani}

E-mail: dermevalsaviani@yahoo.com.br

Recebido em: 27/2/2012

Versáo final recebida em: $17 / 10 / 2012$

Aprovado em: 18/10/2012 